\title{
Siobhan Davies and David Hinton's All This Can Happen (2012)
}

\author{
Nicolas Villodre, Centre National de la Danse
}

\begin{abstract}
This article considers All This Can Happen from an aesthetic point of view and connects this work, resulting from the tight collaboration of the dance film director David Hinton and the contemporary choreographer Siobhan Davies, to the history of avantgarde cinema. Apparently, All This Can Happen is not a dance film, although its rhythmic editing pays tribute to structural films of the seventies and deals with dance. It is not a run-of-the-mill "found footage" opus randomly organized, since the archives were discerningly selected. Subliminal shots, multi-screen images, photographic scratches, graphic signs, and pre-cinema elements associated with contrapunctal sounds produce fascinating effects, strange hallucinations, pure abstractions, and waking dream states, such as one could find in Georges Méliès films, as well as in Abel Gance's, Maya Deren's, or David Hinton's. As a masterpiece worthy of the name, this film demands repeated viewing.
\end{abstract}

Keywords: expanded cinema, avant-garde, split screen, rhythm, simultaneity, hypergraphy

This article seeks to provide a historical framework for considering the aesthetics and technology of All This Can Happen ${ }^{1}$ by tracing the development of various image, sound, and performance practices that have resulted in new approaches to the material of film itself, as well as to screening formats and viewing environments. Drawing on Expanded Cinema and recognizing similar historic experimentation that began as early as the advent of film, this article identifies a rich array of artistic movements and projects that resonate with Siobhan Davies and David Hinton's collaborative film. Indeed, seeing All This Can Happen for the first time immediately stirs the viewer, who may then, if able, revisit the film indefinitely. Each screening is certain to reveal something new within the film's content or form, largely due to the artists' experimental approach, be it a subliminal shot, an incongruent conflux of images whose source the viewer seeks in vain, graphic signs, film strip accidents, or photochemical effects that one might miss upon first viewing. Davies and Hinton used the split screen ${ }^{2}$ and updated the diptych and polyptych forms originally found in painting in order to create this "wide" ${ }^{3}$ film, in every sense of the term: ambitious in its movements and aims, polysemous, broad, and resonant with Expanded Cinema (a movement that includes works such as Abel Gance's 1927 Napoleon and Andy

The International Journal of Screendance 7 (2016). 
Warhol's 1966 Chelsea Girls). Their film allows us to engage with questions that have fascinated critics since the 1920s and remain current, including those surrounding literary adaptations-in this case, Robert Walser's The Walk (1917); ; graphic interactions and the visual value of the image, or its "cineography;" psychophysiology; and the viewer's multi-event perception. All This Can Happen is replete with artistic, aesthetic, and technical elements that all have their own unique histories, often linked to those of the avant-garde.

\section{Pre-text}

With Robert Walser's The Walk as its starting point, the co-directors of All This Can Happen created several byways, at times departing from the original text for purely artistic reasons. They considered it necessary to condense the story, and, caught within the internal logic of editing, even reversed several scenes. This includes the passage to the bookshop found at the opening of the original text, just after a description of men's hats, which was inserted in the film between a brief sequence dedicated to feathers, ribbons, women's hats, and the digressive scene about cafés. This extended frame of reference leads to anachronisms as the images extend beyond the place and period of Walser's real (or imaginary) walk, and these alterations are directly linked to the problem of literary adaptations for the screen, as well as the abstract-figurative dialectic that results from the addition of images to any form of the written word. The artists did not seek to substitute or erase Walser's prose through audiovisual media, which would be more "modern" or all encompassing. Instead, they have proposed visual equivalents capable of rendering the protagonist's universe and situations as described by the Swiss writer.

"All this can happen" as soon as one unapologetically attempts to adapt a book, language, or the sacred-particularly when using film, which is traditionally considered a profane form of art. Despite the alterations and translation, the film's interpretation of Walser by artists from another era and in another medium retains the author's evocative intensity through spoken text (in English, not German), reduced from a story of 100 pages to essential selections in which content and form follow a meandering path. This success is the result of Davies and Hinton's skill applied to the mixing process and documentary research, as well as Danny McGuire's precise structuralist editing (and paradoxically, image gels), in addition to actor John Heffernan's perfect diction spoken off camera. The film neither distorts the content of the book nor the spirit that emanates from it. In this sense, it does not harm the moral rights of the author, which are by nature, "perpetual and imperishable" (at least, according to French law). ${ }^{5}$ Similarly, questions related to divergence (a creative method resembling collage used and justified by Lautréamont), ${ }^{6}$ the ontological separation of image and sound, as well as the photographic element are fundamental to Lettrist and Situationist films, discussed below. 


\section{Hypergraphics and Hypertext}

In 1951, Isidore Isou, creator of the Lettrism ${ }^{7}$ movement, decided to end the synchronicity between audio and image, an inviolable rule of sound cinema, or the "talkie," for both aesthetic and economic reasons. It was not until the 1960s that lighter equipment allowed the artists of cinema verité to truly record direct sound, ${ }^{8}$ while certain N.R.I. directors (narratif-représentatif-industriel [industrial representative narrative], a term proposed by Claudine Eizykman), ${ }^{9}$ such as Fellini, preferred systemically to post-synchronize their films in the studio. This anti-synchronization or "discrepancy" preceded Cage and Cunningham's equivalent within the field of dance, resulting in a series of films that valued text more than image. The exception was Maurice Lemaître's hypergraphic ${ }^{10}$ productions that, following Man Ray, Len Lye and Norman McLaren, ${ }^{11}$ gave particular care to graphic interactions directly applied to photographic emulsion or the filmstrip-illuminations that Isou named "carvings." ${ }^{12}$ Similarly, in All This Can Happen, Davies and Hinton did not hesitate to utilize marks, scratches, and erasure on the filmstrip, allowing them to achieve a number of visual effects.

Marc-Gilbert Guillaumin (later known as a theatre director under the name Marc'O), produced Isou's film Traité de Bave et d'Éternité (Venom and Eternity) that Jean Cocteau selected in 1951 for the Cannes Film Festival. The following year, he published Ion $n^{\circ} 1,{ }^{13}$ a poetry magazine containing texts and manifestos written by Isou, Poucette, Serge Berna, Yolande du Luart, as well as scenarios for films such as Gil J. Wolman's L'Anticoncept (The Anticoncept), Guy-Ernest Debord's Hurlements en Faveur de Sade (Howlings in Favor of Sade) and Tambours du Jugement Premier (Drums of the First

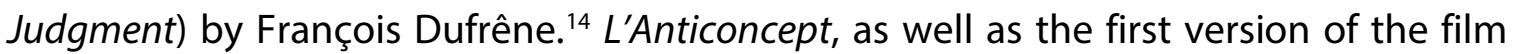
previewed by Debord, ${ }^{15}$ eliminated the use of photography altogether (Wolman alternated circular black and white images projected onto a weather balloon) in favor of a lyrical soundtrack conceived as a collage of shouts, slogans, and phonemes devoid of any precise meaning.

\section{Squaring the Circle}

In his text "Architecture et scénographie" ("Architecture and Scenography"), the French theatre director Jacques Polieri observes the "rupture of the initial architectural (arena) circle," and its "blossoming (Greek and Roman theatre)"16 in the 18th century prior to its Wagnerien (Gesamtkunstwerk) and cinematographic (diorama) transformations. He remarks, "Absurdly, the ideal for the theatre director [...] is to be able to reconstruct his theatre each time." 17 The structure of the circle haunted Appia, Craig, and other contemporary scenographers-from Josef Svoboda ${ }^{18}$ to the equestrian performance artist Bartabas. ${ }^{19}$

In Aubervilliers, France, Bartabas' equestrian theatre Zingaro has recently merged a range of genres in unprecedented experiments that allow audiences to occupy the 
ring traditionally reserved for circus acts. Seated on bleachers attached to a turnstile that slowly rotates clockwise around an uninterrupted flow of horses galloping in the opposite direction, spectators observe horses entering and exiting the background intermittently, varying live horses with those of their video projected shadows. In this performance, ${ }^{20}$ Bartabas frenetically combined horses, their riders, shadows and reflections of the latter, projected from behind or in front, on a 360 degree screen attached to invisible joints and fittings. The performance was difficult to install, unprofitable, and suffered from record low attendance. Yet it achieved the scenographic utopia of theatre and film reformists, including those mentioned above.

\section{Expanded Cinema}

Exploring All This Can Happen from the perspective of Expanded Cinema, an artistic movement that saw film leave its home base and enlarge its horizons, can be particularly useful. This comparison is not meant to imply that Davies and Hinton's film tends towards the theatrical, despite its captivating voice over, or hörspiel: Chu-Li Shewring's sound design is neither a simple illustrative audio track nor is it a redundant mix that can be classified as bruitiste montage, or a film without images (minimalist film for which the prototype is Walter Ruttman's Wochenende [Weekend],1930). All This Can Happen eschews photographic or cinematic reproduction and ensures a unique sensorial experience-even if its material, the DCP (Digital Cinema Package), assures, at least theoretically, a certain durability, stability, and invariability. However, the formula of the polyvision "format" (to borrow a concept important to filmmaker Abel Gance ${ }^{21}$ and musicologist, film theorist, and cinéphonies producer Émile Vuillermoz), ${ }^{22}$ or multi-screen projection, presents actions, angles, and photographs from diverse sources simultaneously.

Gance designed visual triptychs beginning in 1925 for his film Napoléon ${ }^{23}$ and created several others with surprising efficiency despite the fact that they were very difficult to screen. In one sense, this juxtaposition of two or more film images aimed to impress, occupying the entire field of vision to "furnish the space" (as Satie claimed to "furnish" the length of his songs on continuous loop $)^{24}$ in Byzantine ${ }^{25}$ or Orientalist ${ }^{26}$ styles. Alternately, horror vacui (fear of empty space) does not entirely explain this cinematic tendency initiated not long after the film's outset. For example, the Cinéorama ${ }^{27}$ project designed by the Lumière operator Raoul Grimoin-Sanson for the Exposition Universelle of 1900 was conceived in search of "extended vision." ${ }^{28}$ This model encircled visitors without immobilizing them (ensuring their gaze remained free, the real goal in this type of experiment), and was also presented by the Bauhaus artist and teacher Herbert Bayer at the Decorative Arts Exposition of 1930 in Paris. ${ }^{29}$ Historically, the idea has ranged from photographic prints hanging perpendicularly at various angles (an idea Bayer went on to systematize in 1936 by creating a device with 360 degree vision) to the Lettrist syncinéma (see Maurice Lemaitre's 1951 film Le film est déjà commencé? [Has the Film Already Started?]), ${ }^{30}$ in addition to CinemaScope, ${ }^{31}$ various 
attempts at creating films in 3D to counteract the threat of television, the Circarama created by Walt Disney and Ub Iwerks, ${ }^{32}$ and the Laterna Magika of Alfréd Radok and Josef Svoboda. ${ }^{33}$

\section{Cinema and Illusion}

Expanded films may aim to create the depiction of illusion, such as a lift in a hot air balloon in Grimoin-Sanson's project. Alternately, at times, the saturation of signs produces an effect that strips a film of reality and renders it close to hallucination, a waking dream state, and abstraction. Between these two extremes, everything that can increase or intensify psycho-physiological sensations, visual commotion, and kaleidoscopic fascination is permitted. In the spirit of Cabaret Voltaire, Francis Picabia, who had just introduced the film Entr'acte during the dance performance Relâche ${ }^{34}$ (created for the final appearance of the Ballets Suédois-and the last public event of the Dada Movement), wrote a "Cine-Sketch"35 featuring Marcel Duchamp and René Clair's future wife, Bronia Perlmutter, as a nude Adam and Eve. It was held at the Théâtre des Champs-Elysées on New Year's Eve in 1924, and some art historians, including Franck Claustrat, ${ }^{36}$ concede that this short performance marked the beginning of the "happening," the "event," or even performance art. Several years later, in 1928, Germaine Dulac used film to reinforce the representation of a storm during the opera La Tour de Feu (The Tower of Fire). ${ }^{37}$ In the 1960s, experimental filmmakers engaged with expanded film and treated it not only as artistic or technical progress, but also as a genre of its own, situated between Kaprow's "happening" 38 and a gallery or museum installation.

In 1963, the American artist Barbara Rubin created Christmas on Earth in 24 hours, for which she projected two film reels of 34 minutes each. She did not screen one after the other, nor side by side, but one within the other. This small rectangular mise en abyme within a larger rectangle produced a perturbed sense of vision, or alternately, stimulated vision by invigorating it. ${ }^{39}$ Two years later, Rubin's mentor, Jonas Mekas, organized the "Expanded Cinema" festival at the Film-Maker's Cinematheque, which revealed two innovators in the field: Stan VanDerBeek and Robert Whitman. ${ }^{40}$ The latter created a space of "integral vision," the Movie Drome ${ }^{41}$ inside a New York grain silo. Rubin introduced the Velvet Underground to Andy Warhol, an artist who would soon launch into Expanded Cinema with his own $16 \mathrm{~mm}$ diptych and direct sound production, Chelsea Girls (1966). In contrast to Rubin's or Warhol's opus, Merce Cunningham ${ }^{42}$ and Charles Atlas' dance film for two screens, titled Torse (1977), required equally demanding precision similar to Gance's Napoléon. For screening, the two $16 \mathrm{~mm}$ film reels had to be synchronized to the frame.

\section{Simultaneity}

Certainly, editing and mixing undeniably aim, in the case of All This Can Happen, at a form of synchronicity even if it is attained in certain aspects through contrapuntal 
discrepancy or delay effects. The images strip-image deserves to be used in plural form here-often announces what will come in the soundtrack and vice versa. The feeling of "total film" is reinforced by this approach to unison, and the "All" of All This Can Happen is not just an empty promise, an artistic statement, or flirtation, but a complete package. Polyrhythms (an important topic for Ricciotto Canudo) ${ }^{43}$ that occur vertically during the projection of a film reel, following the temporal passage of tracks reserved for audio and the bulk of the strip occupied by the image-and now horizontally, from left to right, on the timeline of digital editing software-find their visual equivalent in All This Can Happen inside the frame, within a still image or a freeze frame, at times underlined by a pause in the image.

The film's approach to visual fragmentation, the choice to "de-realize" or "surrealize" the collage and the layout in a visual patchwork style, entirely assumed by Davies and Hinton, produces an aesthetic shock due to the simultaneity of a range of stimuli. The coincidence of shapes, motifs, framing, and signs that are generally separated as flowing or discontinuous may trouble the viewer. These are not simply actions and movements that occur at the same time on an equal plane in order to justify acceleration or a sense of exaltation without goals, stemming from a futurist or constructivist dynamism generally associated with the city. This serves as a form of "new vision," ${ }^{44}$ to revisit the Bauhaus expression, a shift advocated by John Cage. Indeed, the same principle was applied in 1952 to the "theatrical event of a new genre" 45 mounted by Merce Cunningham, David Tudor, Mary Caroline Richards, Charles Olson, and Robert Rauschenberg at Black Mountain College. According to Cunningham, "Nothing was supposed to represent something other than what was given to see, a tangle of events that viewers could decipher as they pleased." ${ }^{46}$

\section{Body of the Film}

To avoid an imaginary limelight or backdrop, ${ }^{47}$ All This Can Happen seeks to "turn off one and tear the other" as outlined by Émile Vuillermoz. ${ }^{48}$ This tear is not only symbolic, it resembles a chessboard, a checkerboard, or a painting by Piet Mondrian or Paul Klee. The film's simultaneity enjoys a feeling of omnipotence and the "miraculous gift of the ubiquity of film." ${ }^{49}$ Providing lyrical commentary for the film Les Frères Corses (The Corsican Brothers, 1941), based on the eponymous novel by Alexandre Dumas, and directed by the naturalist theatre director and theorist André Antoine, Vuillermoz reminds viewers of film's "powers of evocation," ${ }^{50}$ but additionally addresses questions of a psycho-physiological order related to reception of:

a thousand little photographs of a strip... similar to cells of the human brain: the same speed of lightning reception, the same multiplicity of mirrors positioned to effortlessly juxtapose far off horizons, erasing distances, abolishing the slavery of time and space, embracing simultaneously the present, past, and future, reflecting all the cardinal 
points at the same time, and transporting us within a tenth of a second from one extremity of the universe to another. ${ }^{51}$

During the early planning of All This Can Happen, Hinton hoped to use a collection of essentially pre-cinematic images, and more specifically the chronophotography of Etienne-Jules Maray and his assistant Georges Demenÿ. According to the filmmaker, the production was unable to obtain support from the Cinémathèque Française's current direction, which controls access to these images, initially safeguarded by the Cinémathèque's founder, Henri Langlois. Nevertheless, thanks to science filmmaker Jean-Dominique Lajoux, and in large part to the support of the British Film Institute, Hinton and Davies were able to include several Marey and Demenÿ images in their film. The BFI additionally provided access to rich source material from a wide selection of film genres, ranging from urban films (Ruttman's Berlin, Die Sinfonie der Großstadt [Berlin, Symphony of a Metropolis], 1927) to found footage, in addition to amateur films, newsreels, and fashion shows. Other public and private archives participated as well by providing access to excerpts and still images to which they hold the rights. ${ }^{52}$

Added to All This Can Happen's numerous tones of black and white are those of color film, ranging from the warmest to the coldest shades. Freeze-frames, film scratches, the subjects' inadvertent glances at the camera on screen, in addition to dust particles, stains and unfortunate accidents are all harnessed artistically: they are never concealed, but on the contrary, accentuated. The film invents its own medium by splitting the frame, presenting numerous vignettes, stacking eclectic angles and viewpoints, and aligning and opposing spaces of black and white with color. Rich in content and even more prodigious in signifiers, edited not to the second but to $1 / 25$ of a second (to the frame) like Le Ballet Mécanique (1924)—another film directed by a team of two, Dudley Murphy and Fernand Léger-All This Can Happen condenses Walser's poetic story and allows it to dance. Edited according to an association of ideas, the film follows a musical logic. In this sense, one can say that All This Can Happen found its own unique rhythm.

\section{Biography}

Nicolas Villodre studied visual art at the Université Paris-l, and completed his dissertation in 1983. He was involved with the experimental cinema movement, which was particularly dynamic in France at the end of the 1970s. He has worked the Cinémathèque de la Danse for 30 years and joined the Centre National de la Danse in 2013. In parallel, he has published numerous articles on dance and film for paper and electronic media. 
Email:villodre@noos.fr

\section{Notes}

${ }^{1}$ Davies \& Hinton, All This Can Happen.

2 In commercial film, a model of the genre is Norman Jewison's The Thomas Crown Affair (1968), suggested to the filmmaker by two multiple screen examples presented at the Universal Exposition of Montreal in 1967: Roman Kroiter and Colin Low's In the Labyrinth and Christopher Chapman's A Place to Stand. At the International Fair of New York in 1964, IBM mounted an installation of 17 screens conceived by Ray and Charles Eames, as well as a short film in triptych form, Alexander Hammid and Francis Thompson's To Be Alive (1964), which inspired John Frankenheimer's film Grand Prix (1966). The split screen is closer to collage or photomontage that to the composite photo of the 19th century, or even Alwin Langdon Coburn's (1882-1966) "vortograph" that clearly tended towards abstraction. The multiple images produced by juxtaposition is also distinct in kaleidoscopic photography, generally associated with dreaming or hallucination in fictional films, achieved through prismatic lenses by avant-garde filmmakers such as Dudley Murphey (1897-1968) in Black and Tan Fantasy or Le Ballet Mécanique. (See Delson, Dudley Murphy.)

${ }^{3}$ Translator's note: the author's use of "film large" in French translates literally to "wide film" in English, referring to both historic projection formats as well as hybridity and experimentation in contemporary moving images.

${ }^{4}$ Walser, Der Spaziergang. First english version given in part in the film: Walser, The Walk and Other Stories.

${ }^{5}$ See article L 121 of the French Intellectual Property Code, Law 92-597 1992-07-01, published in JORF on July 3rd 1992 : "L'auteur jouit du droit au respect de son nom, de sa qualité et de son œuvre. Ce droit est attaché à sa personne. II est perpétuel, inaliénable et imprescriptible. II est transmissible à cause de mort aux héritiers de l'auteur. L'exercice peut être conféré à un tiers en vertu de dispositions testamentaires."

${ }^{6}$ To define the notion of divergence, Debord revisited an excerpt from Lautréamont's Poésies // without citing the source: "Plagiarism is necessary. Progress implies it. It stays close to an author's phrasing, uses their expressions, erases a false idea by replacing it with the right one." (Debord, La Société du spectacle, chapter 8, paragraph 207). All translations Marisa C. Hayes.

7 The "Lettrists" preferred the spelling "Letterism" for the Anglicised term, but "Lettrism" is often the most common form found in English.

${ }^{8}$ In France, it is a $16 \mathrm{~mm}$ Éclair camera designed by Coutant, synchronized by quartz to transistor tape recorder with $1 / 4$ Nagra chip bands, further developed by Kudelski.

${ }^{9}$ Eizykman, La Jouissance-Cinéma, 10. 
${ }^{10}$ Hypergraphics, or metagraphics, proposed by Lettrists in 1950 is a system that favors the usage of all types of possible and imaginary signs (letters, sounds, movements, etc.). Isidore Isou observed that in painting, a figurative element placed within an abstract composition was enough to change it into figurative painting while a single sign introduced into a painting, figurative or not, transformed it into a hypergraphic creation, the symbol outweighing the referential material (Isou, Le Lettrisme et l'Hypergraphie).

${ }^{11}$ See Brenez \& Lebrat, Jeune, Dure et Pure; Man Ray \& Tzara, Tristan Les Champs Délicieux; Bouhours, \& Horrocks, Len Lye; Bassan,. Norman McLaren; Holter, Photography Without a Camera; Villodre, "Les Récréations Photographiques à la Fin du XIXe Siècle;" Villodre, "L'Anti-Photographie."

${ }^{12}$ Isou, "Esthétique du Cinéma."

${ }^{13} \mathrm{Ibid}$. Single issue of a magazine edited by the Centre de Création, re-edited in 1999 by Jean-Paul Rocher.

${ }^{14}$ Poet, visual artist, and poster designer who later became part of the New Realism movement.

${ }^{15}$ Cf. Debord Guy. CEuvres Cinématographiques Complètes. Paris: Champ Libre, 1978 ; new publication: Gallimard, 1994. Before founding L'Internationale Situationniste, Debord, Wolman, Brau, Berna and a few others created L'Internationale Lettriste (19521957).

${ }^{16}$ Polieri, Scénographie, Sémiographie, 29.

17 Ibid.

${ }^{18}$ We discovered in 1984 at the Théâtre du Rond-Point (Roundabout Theatre) in Paris the Svoboda's celebrated Laterna Magika and the piece titled Le Cirque Enchanteur (The Enchanted Circle) which made use of $35 \mathrm{~mm}$ film projections on a screen formed like a circular arc, giving the impression that clowns and acrobats were physically coming out of the image.

${ }^{19}$ Bartabas is the creator of equestrian cabaret, merging theatre, dance, world music, and poetry. Bartabas based his troupe at the Fort of Aubervilliers (France) in 1984 within a circus structure designed for him by the architect Patrick Bouchain, the theatre Zingaro. He also founded in 2003 the Equestrian Academy of Versailles, which he considers a classical corps de ballet in which the apprentice riders practice kyudo (Japanese archery), theatre, and dance.

${ }^{20}$ This piece, titled Darshan (2009) is a complex scenography where audience is inside the arena while horses and riders replace spectators, surrounding them. (See Solis, "Darshan, Bartabas à Pas Comptés.")

${ }^{21}$ Only some of his triptychs from Napoléon were used during rare screenings of the film since its premiere in 1927 at the Paris Opera. According to Jean-Jacques Meusy in 1895 (no. 31, 2000, p.153-211), Gance had already engaged fracturing the screen in his first version of J'accuse (1919). Kevin Bronlow states that Émile Vuillermoz proposed the term "polyvision" for this multiple screen format. (See Bronlow, The Parade's Gone By, p. 559). 
${ }^{22}$ The late Noureddine Ghali admired his uncommon personality. For Ghali, Vuillermoz was "a particularly understudied figure in French film criticism and theory. During the First World War and throughout the 1920s, he wrote numerous lucid and thought provoking articles" (Ghali, L'Avant-garde Cinématographique, 327). Vuillermoz, who published a major tome on music, Critique Musicale (1920-1960) was the subject of Pascal Manuel Heu's monograph Le Temps du cinéma : Emile Vuillermoz, père de la critique cinématographique (1910-1930).

${ }^{23}$ Gance, Napoleon.

${ }^{24}$ John Cage revealed an unreleased composition by Erik Satie (1866-1925), in 1949, in the French revue Contrepoints, a model of repetitive music titled Vexations, created, according to specialists, in 1893 , based on a theme and two variations with a very slow tempo that are to be reprised 840 times in a row, which gives the piece a duration of 18 hours. The music was played on piano in 1963 in New York in a marathon played successively by John Cale, John Cage, David Tudor, Chistian Wolff, Phillip Corner, Viola Farber, Robert Wood, MacRae Cook, David Del Tredici, James Tenney and Howard Klein.

25 Satie composed neo-Byzantine pieces, including Gymnopédies (1888) and, particularly Gnossiennes (1891) with Greek and Oriental ornamentation. A close friend of the prose writer and Rosicrucian Joséphin Péladan, Satie wrote L'Hymne pour le Salut au Drapeau du Prince de Byzance for him, recorded by the tenor Nicolaï Gedda in 1987, which EMI released on CD in 1996. It is also known that the Javanese gamelan orchestras invited to the Universal Exposition of 1889 had a large impact on the composer and likely inspired him to explore the use of repetition (see supra Note 24 : Vexations, 1893 and also the music of the film Entr'acte, 1924).

${ }^{26}$ As soon we analyze the relationship between surfaces, we notice that from a distance-whether too far or too close-and with the film at a relative speed of acceleration, that we can no longer distinguish details and separate "visual atoms." This observation stems from "density logic," an important field for Alexandre Papadopoulo, who studied the organization of spiral space in the Persian miniature, the non-figurative art of calligraphy, the abstract art of the arabesque, and the esthetics of the horror of emptiness in L'Islam et l'art musulman.

${ }^{27}$ La Nature, 119-122. A description of this system required ten synchronized cameras and as many projectors. Louis Lumière himself had the idea for the Photorama in 1889, that he patented in December 1900, a system of complete reproduction of the horizon, panorama and no longer optic, like the camera obscura, but photographic, seen during the exhibition "Lumière! Le Cinéma inventé" at the Grand Palais March 27June 14, 2015. See: Les Lumière font leur cinéma, 30.

${ }^{28}$ Meusy, "L'Énigme du Cinéorama," 1-16.

${ }^{29}$ Cf. Quoi, "Herbert Bayer et la vision étendue." Vues d'En Haut. Metz: Éditions du Centre Pompidou-Metz, 2013, 88.

${ }^{30}$ Splicing of the film and diverse interventions in the theatre are described in Lemaître, Le Film est déjà commencé? 
${ }^{31}$ Anamorphic image system developed by 20th Century Fox, used by Hollywood from 1953 to the sixties, based on the Hypergonar and the Anamorphoscope process patented in 1926 by the French Henri Chrétien. https://en.wikipedia.org/wiki/Anamorphosis

${ }^{32}$ The first Circarama film was A Tour Of The West, which was screened at the opening of Disneyland in July 1955. (see: Nielsen, Projecting America).

${ }^{33}$ Ibid. The Laterna Magika was introduced at the World's Fair of 1958 in Brussels. See also end note 18.

${ }^{34}$ See catalogue of Opéra de Paris exhibition: Auclair, Les Ballets Suédois.

${ }^{35}$ This revue, sometimes described as a "cine-sketch" or "cinesketch," was created by Picabia for the "Gala Evening for Rolf de Maré" according to the program. Directed and lit by René Clair, it used stroboscopic effects. Purportedly, Man Ray, who likely photographed the project during rehearsals, played the role of a gossip, Jean Börlin performed as a police officer, and the "Isadorable" Elisabeth Toulemont (alias Caryathis) performed to the music by the group "Six." Poems were likely recited by Yvonne George while the Georgian orchestra played hot jazz. (Garafola, Legacies of Twentieth-Century Dance, 114). According to Carole Boulbès, the theatrical equivalents of practice-based research in slow motion, acceleration, and simultaneity were proposed (Boulbès, Francis Picabia, Écrits critiques, 555).

${ }^{36} \mathrm{Cf}$. Auclair, Les Ballets Suédois.

${ }^{37}$ Lyrical drama in three acts by Sylvio Lazzari, staged at the Paris Opera by Pierre Chéreau, choreographed by Nicola Guerra, including a projected image of rough waves that traversed various painted set backdrops by Maxime Dethomas. See: Bibliothèque de France's notice FRBNF42047774 referring to Wolff, Stéphane. L'Opéra au Palais Garnier (1875-1962). Paris: 1962. This interaction between film and performance is found more recently in ballets, such as Lucinda Childs' Dance (1979), a movement suite synchronized to a $35 \mathrm{~mm}$ film by Sol LeWitt projected at the back of the stage (Boisseau, "La 'Dance' Perpétuelle de Lucinda Childs,"); or Merce Cunningham's Biped (1999), multimedia choreography punctuated by giant 3D images of dance patterns and abstract forms created by digital artists Shelley Eshkar and Paul Kaiser. (Dahan \& Gauville "Danse: Entretien Musical Autour.")

${ }^{38}$ The term "Happening" was used for the first time by Allan Kaprow in 1957 in order to qualify an artistic "performance" (Kaprow, Allan. "Happenings in the New York Scene." Art News, May, 1961, republished in: Kaprow, Essays on the Blurring of Art and Life.

${ }^{39}$ In a number of examples, the effect is obtained during projection. The film reel is not necessarily wider, and the question of anamorphosis is not involved. This is the case for Man Ray who screened films by Méliès in color on dancers dressed in white during an outdoor party given in 1930 by Anna-Letizia Pecci-Blunt; or Werner Nekes directing flickering images from his Schnitte für ABABA (1967) onto a pine forest (Noguez, Cinéma \&, 117).

${ }^{40}$ Whitman presented Prune Flat, a double image film played by Mimi Stark, Simone Forti and Lucinda Childs. Cf. Uroskie, Expanded Cinema, 133

${ }^{41}$ Bouhours, Quel cinéma, 166-167. 
${ }^{42}$ For Cunningham's ballet, Variations V (1965), VanDerBeek used several screens onto which a montage of $16 \mathrm{~mm}$ publicity images, animated films, B-grade television, as well as abstract electronic deformations created by Nam June Paik were projected. These experimental films can be seen in the record of the piece directed one year later by Arne Arnborn for the German TV channel NDR.

${ }^{43}$ Guido, L'Age du rythme, 194-200.

${ }^{44}$ Moholy-Nagy, Laszlo. The New Vision and Abstract of an Artist. New York: Wittenborn, 1947.

${ }^{45}$ Vaughan, Merce Cunningham: Fifty Years, 65.

${ }^{46} \mathrm{Ibid}$.

${ }^{47}$ Translator's note: These are metaphorical terms used in Émile Vuillermoz's writing on film to distinguish new representations of space and time within the cinema as it departed from the use of theatrical backdrops and other stage conventions (Vuillermoz, "Devant l'Écran," 3).

${ }^{48}$ Ibid.

${ }^{49}$ Ibid.

$50 \mathrm{lbid}$.

${ }^{51}$ Ibid.

52 The Yorkshire Film Archive, British Pathé, the Wellcome Library, the London AP Archive, the British Movietone, the Religious Society of Friends in Britain, the National Grid PLC, Catalyst Housing, Les Films du Jeudi, Argos Films, the Collège de France, the Museum of London, the Library of Congress, John Martin, the Photographic Society, the Science Museum, etc.

\section{References}

All This Can Happen. Dir. Siobhan Davies et David Hinton. UK, 2012. Digital Video.

A Place to Stand. Dir. Chirstopher Chapman. Canada: 1967.65 mm Film.

Auclair, Mathias (ed.). Les Ballets Suédois, Une Compagnie d'Avant-garde (1920-1925).

Montreuil : Gourcuff Gradenigo, 2014.

Bassan, Raphaël. Norman McLaren, le Silence de Prométhée, Paris: Paris Expérimental, 2004.

Berlin, Die Sinfonie der Großstadt/Berlin: Symphony of a Great City. Dir. Walter Ruttman. Germany: 1927.35 mm Film.

Black and Tan Fantasy. Dir. Dudley Murphy. USA: 1929. 35 mm Film. 
Boisseau, Rosita. "La 'Dance' Perpétuelle de Lucinda Childs," Le Monde, 22 octobre 2014.

Bouhours, Jean-Michel. Quel cinéma. Paris: JRP-Ringier \& Les Presses du Réel, 2010.

Bouhours, Jean Michel et Roger Horrocks. Len Lye, Paris: Centre Pompidou, 2000.

Boulbès, Carole. Francis Picabia, Écrits Critiques. Paris: Mémoire du Livre, 2005.

Brenez, Nicole et Christian Lebrat. Jeune, Dure et Pure : une Histoire du Cinéma d'Avantgarde et Expérimental. Paris: Cinémathèque Française \& Mazzotta, 2000.

Bronlow, Kevin. The Parade's Gone By. Berkeley: University of California Press, 1968.

Cage, John. "Raison d'être de la Musique Moderne." Contrepoints, Une revue de musique, $\mathrm{n}^{\circ}$ 6. Paris: Richard Masse, 1949.

Chelsea Girls. Dir. Paul Morrissey and Andy Warhol. USA: 1966. 2 x 16 mm Film.

Christmas on Earth. Dir. Barbara Rubin. USA: 1963. 2 x 16 mm Film.

Code de la Propriété Intellectuelle, article L 121, loi 92-597 1992-07-01, JORF, 3 juillet 1992.

Dahan, Eric et Hervé Gauville. “Danse: Entretien Musical Autour de 'Biped,' Dernière Création de Merce Cunningham - Gavin Bryars en Cunningham Majeur," Libération. 11 novembre 1999.

Debord, Guy. La Société du Spectacle. Paris: Buchet/Chastel, 1967.

Delson, Susan B. Dudley Murphy: Hollywood Wild Card. Minneapolis: University of Minnesota Press, 2006.

Dufrêne, François. Tambours du Jugement Premier. Film sans image, France: 1952, rééd. 1981.

Eizykman, Claudine. La Jouissance-cinéma. Paris: UGE, 1975.

Entr'acte. Dir. René Clair and Francis Picabia. France: 1924. 35 mm Film.

Garafola, Lynn. Legacies of Twentieth-Century Dance. Middletown: Wesleyan University Press, 2005.

Ghali, Noureddine. L'Avant-garde Cinématographique en France dans les Années Vingt. Paris: Paris Expérimental, 1995.

Grand Prix. Dir. John Frankenheimer. USA: 1966. 65 mm Film. 
Guido, Laurent. L'Age du Rythme. Lausanne: Payot, 2007.

Guillaumin, Marc-Gilbert (Marc'O). Ion, 1. Paris: Centre de Création, 1952.

Heu, Pascal Manuel. Le Temps du Cinéma: Émile Vuillermoz Père de la Critique Cinématographique (1910-1930). Paris: L'Harmattan, 2003.

Holter, Patra. Photography Without a Camera. New York/Londres: VNR/Studio Vista, 1972.

Hurlements en Faveur de Sade / Howlings in Favor of Sade. Dir. Guy Debord. France: 1952. $35 \mathrm{~mm}$ Film.

In the Labyrinth. Dir. Roman Kroitor, Colin Low, and Hugh O'Connor. Canada: 1967. 70 mm Film.

Isou, Isidore. "Esthétique du Cinéma," in Ion, 1. Paris: Centre de Création, 1952 . Fuvres de Spectacle. Paris: Gallimard, 1964. . Le Lettrisme et l'Hypergraphie dans la peinture et la sculpture contemporaines. Paris: Jean Grassin, 1961. J'accuse. Dir. Abel Gance. France: 1919. 35 mm Film. Kaprow, Allan. Essays on the Blurring of Art and Life. Berkeley: University of California Press, 1993.

L'Anticoncept. Dir. Gil Wolman. France: 1952. 35 mm Film.

Le Ballet Mécanique. Dir. Fernand Léger and Dudley Murphy. France: 1924. 35 mm Film. Le Film est Déjà Commencé? Dir. Maurice Lemaître. France: 1951. 35 mm Film. Les Frères Corses/The Corsican Brothers. Dir. André Antoine. France: 1917. 35 mm Film. Lemaître, Maurice. Le Film est Déjà Commencé? Paris: André Bonne, 1952. Mareschal, G. La Nature, Paris: 21 juillet 1900, p.119-122.

Meusy, Jean-Jacques. "L'Énigme du Cinéorama," Archives, 37. Toulouse: Institut Jean Vigo, 1991.

Meusy, Jean-Jacques. "La Polyvision, Espoir Oublé d'un Cinéma Nouveau," 1895, 31. Paris: AFRHC, 2000.

Moholy-Nagy, Laszlo. The New Vision and Abstract of an Artist. New York: Wittenborn, 1947. 
Napoléon. Dir. Abel Gance. France: 1927. 35 mm \& 3 x 35 mm Film. Nielsen, Sarah Dawn. Projecting America: Films at the Brussels World's Fair of 1958. Los Angeles: University of Southern California, 2000.

Noguez, Dominique. Cinéma \&. Paris: Paris Expérimental, 2010.

Odicino, Guillemette. "Les Lumière font Leur Cinéma." Télérama, édition spéciale, Paris: mars 2015.

Papadopoulo, Alexandre. L'Islam et l'art Musulman. Paris: Citadelles \& Mazenod, 1976.

Polieri, Jacques. Scénographie, Sémiographie. Paris: Denoël/Gonthier, 1971.

Quoi, Alexandre. "Herbert Bayer et la Vision Étendue." Vues d'en Haut, Metz: éditions du Centre Pompidou-Metz, 2013.

Ray, Man \& Tristan Tzara (preface) Les Champs Délicieux. Paris: 1922.

Satie, Erik. Mélodies. L.P. Record. Issy-les-Moulineaux: EMI Music France, 1987.

Solis, René. “Darshan, Bartabas à pas comptés.” Libération, Paris: 10 décembre 2009.

The Thomas Crown Affair. Dir. Norman Jewison. USA: 1968. 35 mm Film.

To Be Alive. Dir. Alexander Hammid and Francis Thompson. USA: 1964. 3 x 35 mm Film.

Torse. Dir. Charles Atlas and Merce Cunningham. USA: 1977. 2 x 16 mm Film

Traité de Bave et d'Éternité / Venom and Eternity. Dir. Isidore Isou. France: 1951.35 mm Film.

Uroskie, Andrew V. Expanded Cinema and Postwar Art. Chicago: The University of Chicago Press, 2014.

Variations V. Dir. Arne Arnborn. Germany: 1966. 16 mm Film.

Vaughan, David. Merce Cunningham: Fifty Years. New York: Aperture, 1997.

Villodre, Nicolas. "Christian Schad Période Dada." Photographies, 7. Paris : mai 1985. . "Les Récréations Photographiques à la fin du XIXe Siècle." Photographies, 8, Paris : septembre 1985. . "L'Anti-Photographie." Revue d'Esthétique, 7, Paris: Privat, 1984.

Vuillermoz, Émile. “Devant l’Écran”, Le Temps, 16 avril 1917-15 mai 1918.

Vuillermoz Émile. Critique Musicale (1902-1960). Paris: L'Harmattan, 2013. 
Walser, Robert, Der Spaziergang. Frauenfeld \& Leipzig: Huber \& Co, 1917. Walser, Robert, The Walk and Other Stories. Trad. C. Middleton. Londres: John Calder, 1957.

Wochenende / Week-end. Dir. Walter Ruttman. Germany: 1930. 35 mm Film.

Wolff, Stéphane. L'Opéra au Palais Garnier (1875-1962). Paris: L'Entr'acte, 1962. 